\title{
Multiculturalism and Transnational Formations in Tony Kushner's Angels in America
}

\author{
Yvonne Iden Ngwa \\ Higher Teacher Training School. (ENS) Yaoundé \\ ngwa_y@yahoo.com
}

Resum

\section{Multiculturalisme i formacions transnacionals a Angels in America de Tony Kushner}

En aquest article es vol demostrar que la representació del multiculturalisme ambient a Amèrica vist per Tony Kushner és palesa a la seva obra Angels in America a través de formacions transnacionals. La seva especificitat rau en el fet de recórrer els diferents aspectes del multiculturalisme. Les teories postcolonials i postmodernes posen de relleu l'heterogeneïtat que caracteritza les cultures a l'obra i justifiquen el multiculturalisme i el transnacionalisme.

\section{Paraules clau}

Multiculturalisme, formacions transnacionals, Tony Kushner.

\section{RESUMEN}

\section{Multiculturalismo y formaciones transnacionales en Angels in America de Tony Kushner}

En este artículo, se quiere demostrar que la representación del multiculturalismo ambiente en América por Tony Kushner desemboca en formaciones transnacionales en su obra Angels in America. Lo que hace su especificidad es que recorre los distintos aspectos del multiculturalismo. Las teorías postcoloniales y postmodernas ponen de relieve la heterogeneidad que caracteriza las culturas en la obra y justifican el multiculturalismo y el transnacionalismo.

Palabras Clave

Multiculturalismo, formaciones transnacionales, Tony Kushner.

\section{RÉSUMÉ}

\section{Multiculturalisme et formations transnationales dans Angels in America de Tony Kushner}

Dans cet article, on veut montrer que la représentation du multiculturalisme ambiant de l'Amérique par Tony Kushner aboutit à des formations transnationales dans sa pièce Angels in America. Contrairement aux autres articles qui décrivent généralement le multiculturalisme dont regorge la pièce, celui-ci s'intéresse aux différents contours de ce multiculturalisme ainsi qu'aux formations transnationales qui en découlent. Les théories postcoloniale et postmoderne mettent en exergue l'hétérogénéité ainsi que la fragmentation qui caractérisent les cultures qui figurent dans la pièce d'où le multiculturalisme et le transnationalisme.

MoTS CLÉS

Multiculturalisme, formations transnationales, Tony Kushner. 


\section{Abstract}

\section{Multiculturalism and Transnational Formations in Tony Kushner's Angels in America}

This article seeks to prove that Tony Kushner's depiction of the multiculturalism ambient in America results into transnational formations in his play Angels in America. The paper deviates from other works in that it undertakes an in-depth analysis of the multicultural dimension of Kushner's play as well as sheds light on its transnational consequences. The postcolonial and postmodern theories highlight the heterogeneity typical of the cultures presented and justify multiculturalism and transnationalism.

\section{KeYwords}

Multiculturalism, transnational formation, Tony Kushner.

\section{Introduction}

The rich multicultural endowment of Tony Kushner's Angels in America ${ }^{1}$ has attracted much critical attention. In "Alla, Angli, and Angels in America," Allen J. Frantzen notes that the prominence of migration and movement away from racial purity are basic elements of Kushner's thesis about change (Bloom, 2005: 92). This is because Kushner's play brings together characters from different nations, having different sexual inclinations, religious convictions, and political leanings. The contiguity in which they live affects the purity of each of them as they become hybridised.

Jonathan Freedman refers to this same concept of multiculturalism without mentioning the term in "Angels, Monsters, and Jews: Intersections of Queer and Jewish Identity in Kushner's Angels in America." In this article, Freedman posits that Kushner offers "the image of a redeemed community in the guise of a utopian Americaness in which the nation is reconstituted in the image of a postnuclear family made up of quarrelling outsiders" (Bloom, 2005: 113). The utopianism of the late twentieth-century American family (the "postnuclear family") alluded to by Freedman in this quotation derives from the fact that it is one that brings together characters of diverse horizons. And although he uses the term "quarrelling outsiders" to shed light on their differences that stem from their dissimilar cultures, Freedman refers to them as a "family" all the same- a word that connotes togetherness. Clarifying the degree of diversity characteristic of the characters whom the dramatist brings together, the critic mentions the construction of "a redeemed America that can gather gay and straight, black and white, Mormon, Christian and Jew into a collective identity" (ibid). This mixture of different sexual inclinations, races, and religious convictions is cross-cultural hence the notion of multiculturalism.

Like Frantzen's and Freedman's articles, this paper is interested in Kushner's proclivity for multiculturalism in Angels in America. But unlike their works, the article attempts to investigate the different contours of this author's multicultural streak. It further sheds light on the transnational formations that result from the cross-cultural contacts. Hence, the paper hinges on the premise that Kushner's multiculturalism in Angels in America results into transnational formations. It will endeavour to answer the following questions: How does Kushner depict the prevalent 
multiculturalism of America in Angels in America? What are the different transnational formations that result from it? The postcolonial and postmodern theories will be used as critical theories for the analysis of Kushner's play.

\section{The Postcolonial and Postmodern Theories}

According to Bill Ashcroft, Gareth Griffiths, and Helen Tiffin, postcolonial literature resulted from "the interaction between imperial culture and the complex of indigenous cultural practices" (1995: 1). This allusion to the cross-breeding amongst cultures that results in hybridity, mutuality of cultures, and syncreticity is central to the analysis of Angels in America which presents America as a contact zone where many cultures rob off each other. The ensuing hybridisation could be linguistic, cultural, political, racial etc (Ashcroft, Griffith and Tiffin, 2007: 109). Multiculturalism and transnational formations accrue from this interaction of people from other nations and their diverse cultures in a given nation called the contact zone.

A simple definition of "multiculturalism" features in "The Postmulticultural: A Tale of Mothers and Sons." In this article, Harry J. Elam defines this word as "the concept of embracing cultural difference" (2002: 113). Such "embracing" entails the renegotiation of the relationship between cultures in ways that avoid attempts either to unify or to hierarchise them to borrow from Siobhán Shilton (2009: 57). Consequently, pluralism and heterogeneity are inherent to multiculturalism.

Even more illuminating and central to the analysis of Kushner's masterpiece in this paper is a definition of the term by Olga R. Kuharets. This critic avers in this work that, over the last 20 years, the term multiculturalism has become increasingly amorphous. She however adds that in many cases,

It is used to denote a movement that deals with a host of issues involving African Americans, Hispanics, and Native American peoples, either individually or in various combinations, along with issues involving women, gays and lesbians, and people with disabilities. (2001: viii)

It is patent from this definition that multiculturalism is concerned with issues that pertain to gender, sexual preferences, and physical handicaps. It is therefore not limited to national or transnational realities that accrue from cross-cultural contact. Incidentally, Kushner skillfully interweaves these different strands of cultural differences in his play. The consequence of this crossculturalism is a number of transnational formations.

In "The Transnational Turn: Rediscovering American Studies in a Wider World," Robert Gross argues that transnationalism "captures a world of fluid borders, where goods, ideas, and people flow constantly across once sovereign space" (2000: 378). As suggested by the prefix "trans-", the transnational therefore transcends delimitations prescribed by national borders. That is probably why Gross adds that transnationalism is concerned with a world where newcomers sustain a cosmopolitan consciousness, while older minorities, notably African Americans, reconceive themselves in international terms (ibid). In other words, no culture is dominant nor inferior in the encounter of cultures evoked here. Thus, there is no danger of one culture being totally engulfed by another. Rather, the different peoples —as is the case of African Americans mentioned by Gross here- are compelled to redefine themselves against the backdrop of the cosmopolitanism concomitant to the international scenery hence the notion of transnational formation. 
The American Heritage Dictionary of the English Language defines "formation" as "the act or process of forming something or of taking form." It equally adds that a formation is "something formed." Both of these definitions are handy for the elucidation of the meaning of the term "transnational formation" in this paper. While the first definition captures the process of cultural cross-breeding of distinct traits, artefacts, and practices of people from different nations who are contiguous to each other, the second focuses on the consequence of this cross-breeding that results from their contiguity. The term "transnational formation" therefore refers to the dynamics involved in, as well as the end-product of the interaction amongst people from different nations.

The pluralism and fragmentation inherent to multiculturalism and transnationalism point to postmodernism as a suitable critical theory for the analysis of Angels in America in this work. Postmodernism rejects grand, supposedly universal narratives and references individual perception and group construction. This postmodernist stance is reminiscent of Kushner's pluralistic depiction of America's cultural reality. As the postmodernists argue that there is nothing like universal claims of truth, ethics, or beauty, so does Angels in America show that there is no American culture per se but rather a diversity of cultures in the United States of America. Postmodernism advocates the reappropriation and re-contextualisation of familiar cultural symbols and images. In postmodernism, as is the case in the world of the play under study, everything is decentred, provisional and fragmentary.

Jean Baudrillard evokes this pluralistic and fragmentary trait of postmodernism by contending that social reality no longer exists in the conventional sense, but has been supplanted by an endless procession of simulacra (1983: 167-182). Stated otherwise, social reality (and in the case of this paper, culture) is not unique because the individual's perception or the group's construction of what culture is determines which culture is the "American culture" in Angels in America. The same ambivalent and undecidable approach to the meaningfulness of language accounts for the play with language typical of postmodernism. The different tenets of the postcolonial and postmodernist theories examined in this section will enable this article to both highlight the diversity of cultures in Kushner's play and the different transnational formations they form as a result of their contiguity.

\section{Multiculturalism in Angels in America}

Tony Kushner's Angels in America has a cast of about fifteen human characters who hail from diverse horizons and differ in a variety of ways. These characters are Hannah Porter Pitt, her son (Joseph Porter Pitt), and his wife- Harper Amaty Pitt. As indicated by their names, these three are family. And although the playwright does not overtly state their nationality, their surnames "Porter Pitt" suggest an Anglo-Saxon ancestry. The author instead insists on their religious conviction. They are Mormons who are otherwise called The Church of Jesus Christ of the Latter-Day Saints. According to Andrew Jackson, Mormonism originated from the early-nineteenth century visions and revelations of Joseph Smith who was its founder, first president and prophet (2008: 17). As part of America's second Great Awakening around the Western frontier region of New York that proceeded from zealous Christian revivals, they are generally an exclusive group of people who practise isolated communal living at one time (2008: 54). This implies that a Mormon faithful to the teachings of Mormonism would not freely interact with people of other religious convictions.

Yet Kushner puts these Mormons side-by-side with a good number of Jews in this play. Characters like Rabbi Isidor Chemelwitz, Louis Ironson, Roy Cohn, the late Sarah Ironson and Ethel Rosenberg 
are all Jews. Being a Jewish American is not just a race. It is equally a religious conviction. According to biblical tradition, Jews are God's chosen people in the Old Testament from among whom the Messiah (Jesus Christ) came to save mankind. But Jews differ from Christians in that they do not believe Jesus Christ is the Messiah and are still awaiting the coming of their savior. They therefore reject the grace he offers and continue to live according to the Mosaic Law. Rabbi Isidor Chemelwitz, referred to by the playwright as an orthodox Jew, sheds light on the dichotomy between Judaism and Christianity (represented here by Catholicism). This can be seen in the excerpt below:

\author{
Louis: Rabbi, I'm afraid of the crime I may commit. \\ Rabbi Isidor Chemelwitz: Please, mister I'm a sick old man facing a long \\ drive home to the Bronx. You want to confess, better you should find a priest. \\ Louis: But I'm not a Catholic, I'm a Jew \\ Rabbi Isidor Chemelwitz: Worse luck for you, bubbulah. Catholics believe \\ in forgiveness. Jews believe in guilt. (He pats the coffin tenderly) \\ (Kushner 1.5.31) ${ }^{2}$
}

The exchange above results from the fact that Louis, in prey to pangs of guilt because he abandoned his grandmother (Sarah Ironson) whose funeral he is attending long before she died and is considering doing same to Louis (his gay lover), tries to find out what the Jewish Holy Book says about a person who abandons someone he loves in times of great need. It is apparent that the Rabbi thinks that Louis has a sin to confess and, not being able to recognize him as a Jew, suggests he meets a priest to do that. Louis's statement that he is a Jew prompts the Rabbi to establish a major antithetical difference between Catholicism (representative of Christianity) and Judaism. While Christians believe in the saving grace of God, Jews believe in judgment, guilt, and condemnation. Yet in addition to putting a restrictive group of people like the Mormons and the Jews together in his play, the dramatist brings people who subscribe to antithetical religious beliefs (like the Jews and the Christians) together. Prior Walter is an example of such a Christian. He is a WASP — White Anglo-Saxon Protestant.

But then, the playwright more especially emphasises the racial definition of this character whose Anglo-Saxon origins he highlights through the apparitions of Prior's forbears- Prior 1 and Prior 2 who lived in the thirteenth and seventeenth centuries respectively. Prior 2 stresses the English tradition of genealogical consciousness when he refers to a "family as long-descended as the Walters" (Kushner 3.1.93). In connection to this, Frantzen notes the fact that Kushner chooses to trace the lineage of this family right back to the eleventh century in "Alla, Angli, and Angels in America" (Bloom, 2005: 83). He even proceeds to add that Prior is made to represent "the Cultural monolith of WASP America, fixed and unchanging" (Bloom, 2005: 89). Yet, this writer opines that Prior's mention of the Bayeux tapestry suggests some intermingling with Norman blood of Prior's race a few lines later (ibid).

After associating Prior to the culture of stasis typical of White Anglo-Saxon Protestants (WASP), Frantzen comments that - through this character's family line- Kushner rewrites the history of Norman Conquest of Anglo-Saxon England in 1066 (Bloom, 2005: 84). He contends that the claim that the Walter's name was stitched into the Bayeux tapestry, though unfounded, implies

2. The first part of Angels in America which is titled Millennium Approaches. In this edition, it runs from page 1-125. 
that the Prior Walters were not a pure breed but were of Anglo-Norman stock. In other words, somewhere along the family line, there was intermarriage or cross-breeding between an AngloSaxon ancestor and a Norman. Such a claim is plausible for two reasons. Firstly, Prior 1 makes it clear that two bastards had featured in the family's lineage (Kushner 3.1.92). He refuses to include them in the family's genealogical record and that is why he tells Prior Walter that he is the thirtysecond of the family line instead of the thirty-fourth as the latter's mother had told him. Secondly, Frantzen sheds light on the fact that the Bayeux tapestry is a Norman relic in the long tradition of French Historians and politicians (Bloom, 2005: 86). Connecting the Walter's name to the tapestry even erroneously suggests that Kushner is hinting at some cross-breeding along the Walter's family line.

Another race that the author brings into this cross-cultural encounter is the African American race. Belize is African-American in the play. He is a Black, the descendant of a black slave who had been transported to America. Meanwhile, the nurse Emily is an Italian American. This is patent in Act Two Scene Two when she tells Prior that she is Italian American. Meanwhile, Harper desires to have an Eskimo as husband when she imaginarily travels to the Antarctica. Although her journey is not real, the dramatist so bridges the gap between the real and the imaginary that he lists the Eskimo amongst his cast. From the racial point of view therefore, Kushner brings together Jews, Anglo-Saxons/Anglo-Normans, African- Americans, Italian Americans, and even Eskimos.

Another platform for multiculturalism in the play is gender boundaries and sexual inclinations. There is a whole host of queer men in the play: Roy Cohn, Louis Ironson, Belize, THE MAN IN THE PARK and Prior. Joseph Pitt is married to Harper and one would think that they are both heterosexual. But his liaison with Louis at one point in the play shows that he is bisexual. Also, by all indications, the older generation incarnated by characters such as the late Sarah Ironson, Hannah Pitt, Walter Prior's ancestors are all "straight." This can be deducted from the play from a number of clues. In the $6^{\text {th }}$ scene of Act Five, Prior encounters late Sarah Ironson and Rabbi Chemelwitz on the streets of heaven and decides to betray Louis by telling her that her grandson is gay. It is obvious (at the burial scene of Sarah) that Louis has hidden the fact that he is gay from his family (Kushner 1.4. 25-26). Louis's late grandmother's reply is that the boy had always been mixed up even in childhood (Kushner 5.6. 269) 3 $^{3}$ Hannah Pitt is simply shocked by the simple idea that her son is gay when he calls her to say so and concludes that he is just being ridiculous because he thinks that his father had not loved him (Kushner 2.8.81-82). Finally, Prior 1 who does not seem to understand the concept of gay, insists that Prior Walters ought to have a family, and states that he had twelve children by the time he died (Kushner 3.1. 92-93).

Besides the parameters of religious denominations, racial definitions, gender boundaries, and sexual inclinations on which Kushner's interplay of cultures hinge in this play, there are other factors like political leanings and economic systems. Characters like Roy Cohn, Martin Heller- who is presented as a Reagan administration Justice Department flackman - and Joseph Pitt (otherwise referred to as "Royboy") are all Republicans. Roy boasts of the fact that he can call the White House and talk to President Reagan, and better still, to Mrs Reagan anytime he wants. He also mentions his arch hatred for Communism that pushes him to scheme for the death sentence of Ethel Rosenberg because this Jewish matriarch somehow betrayed the regime by showing allegiance to Communism (Kushner 3.5. 113-114). Opposed to this Reaganite clique are advocates of liberalism, reminiscent

3. Having as title Perestroika, the second part of Angels in America runs from page 126-280 of this edition. 
of the Democrats, like Louis and Prior. Louis jilts Joe when he investigates Prior's declaration that his new lover is a Reaganite and is Roy's "boy." He is irked by Joseph's subscription to the republican conservatism that causes him to militate for decisions that sanction gays and penalises the masses (Kushner 4.8. 239-244). He even accuses Joe of being Fascist (243). Contrary to Joe's leanings is Belize's reference to Louis as possible "arrogant, sexual-political Stalinist-slash-racist flag-waving thug" because of the latter's tirades on questions of race, politics, economic policies etc. (Kushner 3.2. 100).

This analysis corroborates Freedman's claim that Kushner's play evokes a community “composed of various forms of others" (Bloom, 2005: 113). He describes this community as one made up of the Mormon, the Jew, the black male drag queen, the WASP man, and the queer Jew (ibid). In conformity with Kuharets's definition of multiculturalism used in this paper, the work studied handles a host of issues that pertain to race (Jewish American, African American, Italian American); issues involving gender and sexual identities (heterosexual, homosexual, and bisexual), and even religious convictions and practices (Mormonism, Judhaism, and Christianity).

It is interesting to note that Kushner adds supernatural entities as part of his cast in this play. In addition to the Angel that severally visits Prior, six other angels sit in council with her in Act Five Scene Five. Equally significant is the fact that these angels are named after the continents of the world: Antarctica, Oceania, Asiatica, Europa, Africanii, Australia (260-262). The Angel that visits Prior represents the American continent. Ghosts as well as disembodied and imaginary beings are also characters in the play. Prior 1, Prior 2, Ethel Rosenberg, and even Roy Cohn (at one point) are all ghosts that feature in the play and interact with the living like any other ordinary character. Meanwhile Mr Lies and the Angel's Disembodied Voice are examples of imaginary characters. Thus, Angels in America can be read as the paroxysm of multiculturalism whereby the earthly and the heavenly; the dead and the living; the real and the imaginary intermingle. As the playwright artfully juxtaposes these characters and gets them to interact with each other, their interaction results into many transnational formations which this paper will presently examine.

\section{The Consequent Transnational Formations}

The first obvious transnational formation that accrues from the melting pot described in the preceding section is the alienation that results from the characters' hybridisation, heterogeneity, and syncreticity. Stephen May posits that the hybridity theory advocates the rejection of totality and foundationalism and "its replacement by a plethora of local identities" (1999: 24). To make this point clear, May avers that hybridity lends itself to a politics of difference which he finds commensurable with multiculturalism (ibid). The consequence of hybridisation is not the total engulfment of one culture by another. Instead, it is the fragmentation of cultures as each culture robs off each other and the different people from these cultures become "multiple agents."

A clear instance of this situation is at Sarah Ironson's burial in the first scene of the play. Rabbi Chemelwitz clearly notes that the dead woman is totally different from her children and grandchildren. He refers to her as "not a person but a whole kind of person" (Kushner 1.1. 16). He proceeds to explain what kind of person Louis's grandmother was by adding that she is amongst the migrants who brought the cultural identity of the Jews from the villages of Russia and Lithuania and fought hard for her descendants not to get corrupted by the cultures of the other immigrants (ibid). But the Rabbi admits that Sarah's struggle is vain as he admits that "pretty soon... all the old 
will be dead." In fact, he refers to her as "the last of the Mohicans" - the title of James Fenimore Cooper's novel of adventure that heralds the extinction of the natives of the American continent.

The alienating effect of the presumed mainstream culture is alluded to in Angels of America when the rabbi wonders whether Eric, the name of one of Sarah's grandson, is a Jewish name (1.1.16). In effect, he refers to all her descendants as people with "goyische names" - "goyische" is a Jewish/ Yiddish term used to refer to something that is not Jewish. To solve this problem, Louis is "Lou" when he is with his family (4. 4. 25-26). But when he is in his cosmopolitan environment, he prefers to be called "Louis." He even gets offended with Belize and finds the latter anti-semitic because he had called him "Lou the Jew" three years before (Kushner 3.2. 101). Even more interesting is the fact that Louis chooses to become "Louise" (the French feminine variety of his name) when he is luring Joe into an amorous escapade with him (Kushner 1.6. 36). He stresses the very last sibilant sound of the name. In addition to doing this, he feints when Joe offers him a handshake and prefers to give him a peck on the cheek before exiting (ibid). Thus Louis is variously "Lou," "Louis," and "Louise." This fragmentation results into a split identity and pluralism.

It is significant that the name "Louis" becomes "Louise" because he acts the role of the female partner in his homosexual relationships. For instance, he asks the MAN IN THE PART to put on a contraceptive and make love to him and the latter does so (Kushner 2.4. 62-63). The fact that he attempts to use both this man and Joe to replace Prior suggests that he is the "female" lover in his gay relationships. Likewise, Joe is an irreproachable and "straight" Mormon to both his wife and mother until he decides to tell them that he is gay. This is because the crush he has on Louis is such that he wants to hold onto their relationship and is ready to give up everything for it. It is only then that Harper understands what his numerous walks to Central Park had been about. It can be inferred that, like Louis who has sex with the stranger in the Park, Joe has been doing same in order to both gratify and hide his homosexual impulses. He hides behind Republican conservatism and Mormonism at the court where he works and for the benefit of Roy Cohn. But when he reveals his real identity to Roy and the latter orders him to break off with Louis and make up with his wife, he attempts to carry on with the mask of respectability.

Roy Cohn himself is another gay who hides behind the Republican conservatism of the Reagan government. When he is diagnosed of AIDS, he attempts to suggest that he has been infected by a whore in Dallas but his doctor - Henry- specifies that it is not a female whore. And much to Roy Cohn's displeasure, he unmasks the latter by adding that Roy has had sex many times with men (Kushner 1.9.50-51). Like the pervert and hypocrite that he is, Roy threatens to destroy his doctor's reputation and practice if it is made known that he has AIDS. He orders Henry to say that he has liver cancer and tells Joe the same lie. He is so keen on hiding behind the veneer of respectability that he prefers to consider himself a heterosexual man who sleeps around with guys rather than acknowledging his homosexuality (Kushner 1.9. 52). He is another character who has a split identity.

It is evident from this analysis that May's assertion that "multiple, shifting and, at times, nonsynchronous identities are the norm for individuals" is apt (May, 1999: 24). The paper has already shown how these characters swop one identity for another whenever their surrounding requires that they do so. These identities are nonsynchronous because, as portrayed, these characters cannot display all these cultural traits at the same time. But in addition to these facts, these identity traits are incompatible. Neither Mormonism nor Judaism condones homosexuality. The Mormon's adhesion to biblical prescriptions and the Jew's subscription to the Mosaic Law of the Old Testament ought to deter these characters from contracting gay relationships. It is recorded in Leviticus 19:22 
of the Holy Bible that, "You shall not lie with a man as with a woman: it is an abomination" (Revised King James Version). The conservatism of the Republican government ought to be another deterrent to its adepts such as Roy and Joe.

The prudery of Anglosaxonism as well as Prior's Protestantism equally ought to inhibit him from indulging in gay practices. But both do not. He was Belize's former lover and is Louis's present lover. At one point of the play, he too puts on a female identity when he decides to wear makeup in order to "hide" from the reality of his newly discovered disease (Kushner 1.7.37). Meanwhile Belize is not only gay. It is equally said that he is a former drag queen. A drag queen is defined as a traditionally male person who dresses in drag and acts in female gender roles with exaggerated femininity. This points to the fact that, though a man, Belize also experiences shifts of identity when he has to act out such a role and as the "female" partner in his past love relationship with Prior.

A new family construct thus emerges from transnational bondings and realities. Freedman refers to this family as the queer family, "a family-as-nation metaphor for a nonprocreative family and nation that includes all forms of family in a new national narrative" (Bloom, 2005: 115). Benilde Montgomery's description of this family prototype in "Angels in America as Medieval Mystery" partly elucidates Freedman's statement. She notes that Kushner's construction of families shows that the traditional prototype is wounded: Sarah Ironson's grandchildren have become assimilated; Joe's father could not love him; Joe abandons Harper; and Roy notes that the Reagans are not really a family because there are no connections amongst them, no love, and they do not even speak to each other except through their agents (Bloom, 2005: 130).

Unlike this traditional family, the new family prototype is neither constructed along bloodlines nor racial definitions. According to Montgomery, it is one in which Roy's "fathers" are "Walter Winchell, Edgar Hoover, Joe McCarthy most of all" (Bloom, 2005: 130). Roy is equally a father to Joe. Hannah poses as the "new matriarch" of this family in replacement of late Sarah Ironson. Unlike the latter, she is liberal enough to smoke cigarettes as well as give necessary support to Prior (a homosexual) and to her addicted daughter-in-law. To borrow from David Savran in "Ambivalence, Utopia, and a Queer Sort of Materialism: How Angels in America Reconstructs the Nation," Joe is her real son and Prior is her surrogate son (Bloom, 2005: 25). The fact that she shows more love and sympathy to her surrogate son is really proof that "biological descent counts for nothing" in this new family definition as earlier noted in this paper.

The ambivalence and undecidability that characterize the notions of identity and the family are echoed in the ambiguity that surrounds the play's genre and the author's use of technics such as the double roles assigned to characters and the use of split scenes. John Clum compares the play to "a Shakespearean romance" (1994: 314). Meanwhile, Janelle Reinelt associates it to avant-garde theatre that bears the imprints of Artaud (Bloom, 2005: 59). Such different categorisations of the same play justify Savran's observation that Angels in America is "a promiscuously complicated play that is very difficult to categorize generically" (Bloom, 2005: 17). Interestingly, both Clum's and Reinelt's classifications are tenably applicable to Kushner's play which merges features of traditional drama (Shakespearean and Sophoclean plays) with those of modern drama (Brechtian plays). Thus, Savran's characterisation of the play as "a promiscuously complicated one" is justified.

Pluralism and ambivalence are also conveyed by the double, and sometimes three or more roles, which the characters are made to play. For example, the same character acting the role of Hannah Porter Pitt is expected to also act out the roles of Rabbi Isidor Chemelwitz, Ethel Rosenberg and Henry - Roy Cohn's doctor. This implies being able to be four different people in one play. And this is even more challenging because the actor/actress acting out the roles will have 
to shift from being a Mormon matriarch to being an orthodox Jew. Next he/she will have to play the part of the ghost of an elderly Jewess who comes back to life to seek revenge on Roy. Finally, he/she will have to be the medical doctor who diagnoses Roy of AIDS. The shifts of personality may not occur in exactly this order but according to the order in which these actors/actresses climb on stage. Once more, Kushner's little regard for racial definitions and gender boundaries is obvious - he gets the same character to indiscriminately play the roles of Mormon/Jew and man/woman in the case of Hannah here. All his characters have two or more roles to act out in this play.

The same multiplicity recurs in the dramatist's recourse to split scenes. Six of these scenes feature in Millennium Approaches and four in Perestroika. Charles McNuly evokes the significance of these scenes in reflecting the play's undecidability when he opines in "Angels in America: Tony Kushner's Thesis on the Philosophy of History" that "Kushner uses split scenes to make more explicit the contrapuntal relationship between these seemingly disconnected narratives" (Bloom, 2005: 48). The seemingly disconnected narratives this critic identifies in the "Kushnerian territory" are racism, sexism, homophobia, moral erosion, and drug addiction. For example, the first split scene in Act One Scene Five that juxtaposes Joe and Harper in their home in Brooklyn and Louis and Rabbi Chemelwitz at the cemetery augurs Joe's and Louis's respective break from Mormon respectability and Jewish orthodoxy. These two men later become a homosexual couple in the play. By thus blending the otherwise irreconcilable, Kushner achieves "the dissolution and the blending of identities" to borrow from Reinelt (Bloom, 2005: 64).

The combined effect of the different nationalities of these characters and their little inclination towards respecting traditional gender boundaries affects the language they speak. Rosenwald Lawrence quotes Meir Sternberg as commenting that literary art finds itself confronted by the formidable mimetic challenge - that of representing the reality of polylingual discourse through a communicative medium which is normally unilingual (2008: 1). Kushner faces this challenge and chooses to resolve it in his own unique way. His play is mostly written in English but this English varies from Standard English, working class and slang English, African American English, and what Leon Kobrin is quoted as referring to as "Yiddishized English" (2008: 83). In addition to this, Kushner punctuates his text with other languages such as Yiddish, Italian, and French. It can be said, in a nutshell, that the language used in the text is a transnational formation.

The first time Prior Walters speaks in Act One Scene Four, his English is standard. He responds to Louis's allusion to the rabbi in these words, "A definite find. Get his number when you get to the graveyard" (25). This refined English is in keeping with his Anglo-Saxon ancestry which Louis traces to the coming of the Puritans on board the Mayflower (Kushner 2.3. 57). But being the thirtysecond of the Walters's lineage (without counting the bastards) and having lived in America all these years, Prior easily switches to using slangs such as "Feh" and "dyke." According to The Dictionary of American Slang, "Feh" is a word of Yiddish origin; an interjection that expresses disgust. Meanwhile "dyke" is the slang word for lesbian. It is obvious that Prior's work as occasional club designer and caterer as well as his homosexual relationship with Louis - a Jewish American - very much expose him to this working class and slang variety of the English Language. Other characters through whom the dramatist achieves linguistic transnational formations are Rabbi Chemelwitz, Emily, Prior, and Belize.

As an orthodox Jew, Rabbi Chemelwitz either speaks “yiddishized English" in the play or simply speaks Yiddish. An instance has already been cited where the rabbi describes the names of Sarah's 
descendants as "goyische names" (goyische being a Yiddish term). Moreover, Freedman notes that the syntax of the language spoken by the rabbi in Sarah Ironson's eulogy is "stage Yiddish" (Bloom, 2005: 106). He is also one of those who speaks downright Yiddish in the play as is the case when he quotes King Lear (Kenig Lear), "Sharfer vi di tson fun a shlang iz an umdankbar kind!" (Kushner 1.5.31). It is only when Louis states that he does not speak Yiddish that the rabbi translates King Lear's famous statement that deplores a child's ingratitude into English. Meanwhile, Emily speaks Italian to Prior in his hospital room (Kushner 3.2.104).

But it is in the speaking of the French language that these characters' blurred notion of sex distinction is most evident. It is common for the gay characters to use the feminine article, pronoun, or genre of a word to refer to a masculine person or entity. This can be seen in Act Two Scene Five in the exchange between Prior and Belize:

Prior: Miss Thing.

Belize: Ma cherie [sic] bichette.

Prior: Stella.

Belize: Stella for star. Let me see. (scrutinizing Prior) You look like shit, why yes you do, comme la merde!

Prior: Merci. (Kushner 2.5.65)

"Bichette" used to address Prior here is not proper because he is a man. And since in the French language the genre of a noun determines the genre of its determiner and any adjective used to qualify it, the feminine possessive "ma" and descriptive adjective "cherie" have been used to both determine and qualify the word "bichette." Hence, as a man, Prior ought not to be called "bichette." But since Belize and Prior are both gay and were lovers in the past, it can be deduced that their sexual inclination and past experience as lovers conditions their language use in this excerpt. Belize fondly refers to Prior as "bichette." Prior likewise chooses to disregard Belize's masculinity. $\mathrm{He}$ refers to him as "miss" and calls him "Stella." Transnationalism is also achieved in this extract because French is spoken here by an African American and an Anglophone American and not by a Francophone American. The play is strewn with such code switches from English to the different languages listed in this analysis.

\section{Conclusion}

In view of the above analysis, it can be concluded that Tony Kushner's Angels in America delineates a pluralistic world encapsulated in the notion of multiculturalism. The play's cast comprises people of diverse races, who have different religious convictions, sexual inclinations, and political leanings. And since no single cultural artefact or practice totally engulfs the other, the accruing multiplicity creates ambivalence and undecidability. Delimitations such as national borders, individual identities, gender boundaries, and linguistic entities have given way hence the emergence of new forms and fluid concepts. The second and third sections of this paper have examined these different cultural strands and the transnational formations that result from

[sic]. Thus written without the "accent aigu" by the playwright. 
them. It can be inferred that, by equally blending the earthly and the heavenly, the dead and the living, as well as the natural and the supernatural, Kushner's play heralds the coming of a new era. This might be the age in which the American will be as ambivalent as Kushner's angel that is neither mammal nor bird, neither male nor female because of cross-cultural encounters. "Angels in America" can therefore be read as a metaphor of the American of this new age.

\section{Bibliography}

ASCHCROFT. B., GRIFFITHS G. and TIFFIN H., (eds.), The Postcolonial Reader, New York, Routledge, 1995.

ASCHCROFT. B., GRIFFITHS G. and TIFFIN H., (eds.), Post-colonial Studies: The Key Concepts, $2^{\text {nd }}$ ed, Routledge, London, 2007.

BAUDRILLARD J., Simulacra and Simulations, Jean Baudrillard: Selected Writing, Ed. Mark Poster, Trans Paul Foss, Paul Patton and Philip Beitchman, Semiotext(e), New York.

CLUM J., Acting Gay: Male Homosexuality in Modern Drama, Columbia University Press, New York, 1994.

ELAM (Jr), H.J., "The Postmulticultural: A Tale of Mothers and Sons" Crucible of Cultures: Anglophone Drama at the Dawn of a New Millennium, ed. Marc Maufort and France Bellars, Peter Lang, Brussels, 2002, pp. 113-128.

FRANTZEN A.J., "Alla, Angli, and Angel in America," Bloom's Modern Critical Views: Tony Kushner, Chelsea House Publishers, Phidelphia, 2005, pp. 68-102.

FREEDMAN J., "Angels, Monsters, and Jews: Intersections of Queer and Jewish Identity in kushner's. Angels in America," Bloom's Modern Critical Views: Tony Kushner, Chelsea House Publishers, 2005, pp. 103-122.

GROSS R., "The Transnational Turn: Rediscovering American Studies in a Wider World," Journal of American Studies, 34 .3, 2000, pp. 373-93.

JACKSON A., Mormonisom Explained: What latter-Day Saints Teach and Practice, Crossway Books, Wheaton, 2008.

KEOWN M., MURPHY D., and PROCTER J. (eds), Comparing Postcolonial Diasporas, Palgrave Macmillan, New York, 2009.

KIPFER A.B. and CHAPMAN R.L., The Dictionary of American Slang, $4^{\text {th }}$ ed, Harpercollins Publisher, New York, 2007.

KUHARETS O.R. (ed.), Venture into Cultures: A Resource Book of Multicultural Materials and Programs, $2^{\text {nd }}$ ed, American Library Association, Chicago, 2001.

KUSHNER T., Angels in America, Theatre communications Group, New York, 1995.

MAY, S. (ed.), Critical Multiculturalisim: Rethinking Multicultural and Antiracist Education, Palmer Press, London, 1999.

MONTGOMERY B., "Angels in America as Medieval Mystery," Bloom's Modern Critical Views: Tony Kushner, Chelsea House Publishers, Philadelphia, 2005, pp.123-134.

PATWELL J. (ed.), The American Heritage Dictionary of the English Language, $3^{\text {rd }}$ ed, Boston, Houghton Mifflin, 1992.

REINELT J., "Notes on Angels in America as American Epic Theater," Bloom's Modern Critical Views: Tony Kushner, Chelsea House Publishers, Philadelphia, 2005, pp. 59-68. 
ROSENWALD L., A Multilingual America: Language and the Making of American Literature, Cambridge University Press, Cambridge, 2008.

SAVRAN D., "Ambivalence, Utopia and a Queer Sort of Materialism: How Angels in America Reconstructs the Nation," Bloom's Modern Critical Views: Tony Kushner, Chelsea House Publishers, Philadelphia, 2005, pp. 15-42.

THE TRINITARIAN Bible Society, The Holy Bible, Revised King James Version, Cambridge University Press, Cambridge, 1981. 